\title{
Genetic structure and diversity of the blueface darter Etheostoma cyanoprosopum, a microendemic freshwater fish in the southeastern USA
}

\author{
Brook L. Fluker ${ }^{1, *}$, Kenny D. Jones ${ }^{1,3}$, Bernard R. Kuhajda ${ }^{2}$ \\ ${ }^{1}$ Department of Biological Sciences, Arkansas State University, Jonesboro, AR 72467, USA \\ ${ }^{2}$ Tennessee Aquarium Conservation Institute, Chattanooga, TN 37405, USA \\ ${ }^{3}$ Present address: Department of Biological and Environmental Sciences, University of West Alabama, Livingston, \\ AL 35470, USA
}

\begin{abstract}
Darters represent one of the most diverse groups of freshwater fishes in North America, but approximately $33 \%$ of the 215 recognized species are considered imperiled on the IUCN Red List. Discovery and description of new darter species continue at a relatively rapid pace, with many exhibiting microendemic geographic distributions and little baseline data for conservation decisions. The blueface darter Etheostoma cyanoprosopum is a newly described species that occupies $<20 \mathrm{~km}$ of stream reaches in the Bear Creek system of the Tennessee River drainage and the Hubbard Creek system of the Black Warrior River drainage in the Mobile Basin (Alabama, USA). In addition to restricted distribution, the species is threatened by habitat degradation and several natural and man-made barriers that putatively fragment connectivity among populations. This study used microsatellite DNA and mitochondrial DNA (mtDNA) data with comparisons to the relatively broadly distributed sister species (bandfin darter E. zonistium) to evaluate multiple objectives regarding genetic connectivity and diversity among blueface darter populations. Analysis of mtDNA data indicated a lack of historical structuring across the Tennessee-Black Warrior River drainage divide and within the Bear Creek system. However, microsatellite-based Bayesian cluster analyses and $F$-statistics suggested contemporary isolation across the drainage divide and evidence for reservoir-induced fragmentation within the Bear Creek system. Compared to the sister bandfin darter, blueface darter populations exhibited reduced levels of genetic diversity, rendering them more susceptible to local extirpation and reduced fitness. Continued monitoring and quantitative ecological studies are recommended to understand population-specific measures of occurrence and abundance.
\end{abstract}

KEY WORDS: Conservation genetics $\cdot$ Microsatellites $\cdot$ mtDNA

\section{INTRODUCTION}

With approximately 215 species, darters (Percidae: Etheostomatinae) are one of the most specious groups of freshwater fishes in eastern North America (Page 1983, Lundberg et al. 2000, Mayden et al. 2006, Near et al. 2011). Although darters have been

${ }^{*}$ Corresponding author: bfluker@astate.edu one of the most studied groups of fishes in North America, ongoing taxonomic studies and recent advances in molecular techniques have led to the discovery and description of 26 new species since 2007 (approx. 2 new species described per year), and another 40 are awaiting formal description (estimated from Near et al. 2011). Despite high species

(C) The authors 2019. Open Access under Creative Commons by Attribution Licence. Use, distribution and reproduction are unrestricted. Authors and original publication must be credited. 
diversity, approximately $33 \%$ of darters are categorized on the IUCN Red List (IUCN 2018) as follows: Extinct (1 species), Critically Endangered (5), Endangered (17), Vulnerable (32), and Near Threatened (17). While many darters have broad geographic distributions and corresponding flexibility in habitat use, the large majority have small geographic distributions, specific habitat requirements, and unique life-history strategies (Page 1983, Page et al. 1985, Turner et al. 1996). Of particular interest for conservation are darters that exhibit microendemism, with distributions that span small geographic footprints, single river drainages, or even just a few streams or springs (e.g. Mayden et al. 2005, Hollingsworth \& Near 2009, Fluker et al. 2010, 2014a). With a few exceptions, most of the darters listed under the Endangered Species Act or on the IUCN Red List have highly endemic or microendemic geographic distributions (Jelks et al. 2008). Given the rapid rate of new darter species descriptions, most of which have microendemic distributions, there is a need to determine basic information for these species, such as population genetic structure and diversity, life-history characteristics, and habitat use, that may help categorize conservation status and guide conservation planning.

The blueface darter Etheostoma cyanoprosopum Near \& Kozal, 2017, is a newly described species with an extremely limited geographic range, restricted to $<20 \mathrm{~km}$ of 2 stream systems in northwestern Alabama, USA (Boschung \& Mayden 2004, Kuhajda 2004, Kozal et al. 2017a; Fig. 1). Although the species was recently described, it has been informally recognized as distinct since 1995 (Kuhajda \& Mayden 1995, Boschung \& Mayden 2004, Kozal et al. 2017a), and numerous status surveys have been conducted since (Kuhajda 2004). Because of the informal recognition as distinct for $>20 \mathrm{yr}$, this rare species has been designated as threatened by the American Fisheries Society since 2000 based on the following criteria: criterion 1-'present or threatened destruction, modification, or reduction of a taxon's habitat or range' and criterion 5-'a narrowly restricted range' (Warren et al. 2000, Jelks et al. 2008). In addition, the species has been assigned a NatureServe global rank of G1 (critically imperiled; NatureServe 2018). Distributional patterns and estimated timing of divergence from sister populations of bandfin darter E. zonistium suggest that the blueface darter has a naturally small geographical distribution. For example, the species is only known from upland habitats on the western margin of the Cumberland Plateau, where it is isolated from bandfin darter populations by approxi- mately 75 river $\mathrm{km}$ and the transition to lowland Coastal Plain habitats (Kuhajda 2004, Kozal et al. 2017a). Divergence between the blueface darter and close relatives occurred 2.9 (1.6-4.9) million years ago (mean and upper and lower bounds of the estimate) (Kozal et al. 2017a), and upland habitats of the Cumberland Plateau have remained relatively stable since mid-Mesozoic times (Starnes \& Etnier 1986). Given the isolation of blueface darter populations in the uppermost reaches of the streams it occupies, and its relatively recent history there, it is unlikely that the species had a historically larger geographic distribution.

In addition to its microendemic distribution, there is concern about natural and man-made barriers that putatively fragment connectivity for the blueface darter across its range. First, the species has a peculiar distribution in adjacent headwater tributaries of 2 distinct drainage basins (Fig. 1): the Tennessee River (Bear Creek system) and the Black Warrior River of the Mobile Basin (Hubbard Creek system). It is unclear whether populations across this drainage divide share connectivity, but it has been hypothesized that the blueface darter gained access to Hubbard Creek via headwater piracy from Upper Bear Creek (Dycus \& Howell 1974, Boschung \& Mayden 2004). Both mitochondrial DNA (mtDNA) variation and microsatellite DNA-based cluster analysis of Kozal et al. (2017a) suggested no clear pattern of genetic structuring between blueface darter populations across the Tennessee-Black Warrior River drainage divide; however, explicit tests for genetic structure among drainages were beyond the scope of the study, and sample sizes of the Bear Creek population were small $(\mathrm{n}=5)$ for microsatellite-based analyses. Understanding whether blueface darter populations are isolated across the Tennessee-Black Warrior River drainage divide has clear conservation and management implications in terms of defining population boundaries and developing sound management strategies for this rare species. Second, population connectivity among tributaries of the Upper Bear Creek system is potentially restricted by Upper Bear Creek Reservoir (Fig. 1). Status surveys in 1999 and 2002 failed to locate blueface darters at historically known localities downstream of Upper Bear Creek Reservoir (Kuhajda \& Mayden 2002). Thus, all localities in the Bear Creek system with contemporary blueface darter occurrences are restricted to the upper reaches of Little Bear, Turkey, and Bear creeks, which drain independently into Upper Bear Creek Reservoir (Fig. 1). The potential for reservoirinduced fragmentation of blueface darter popula- 

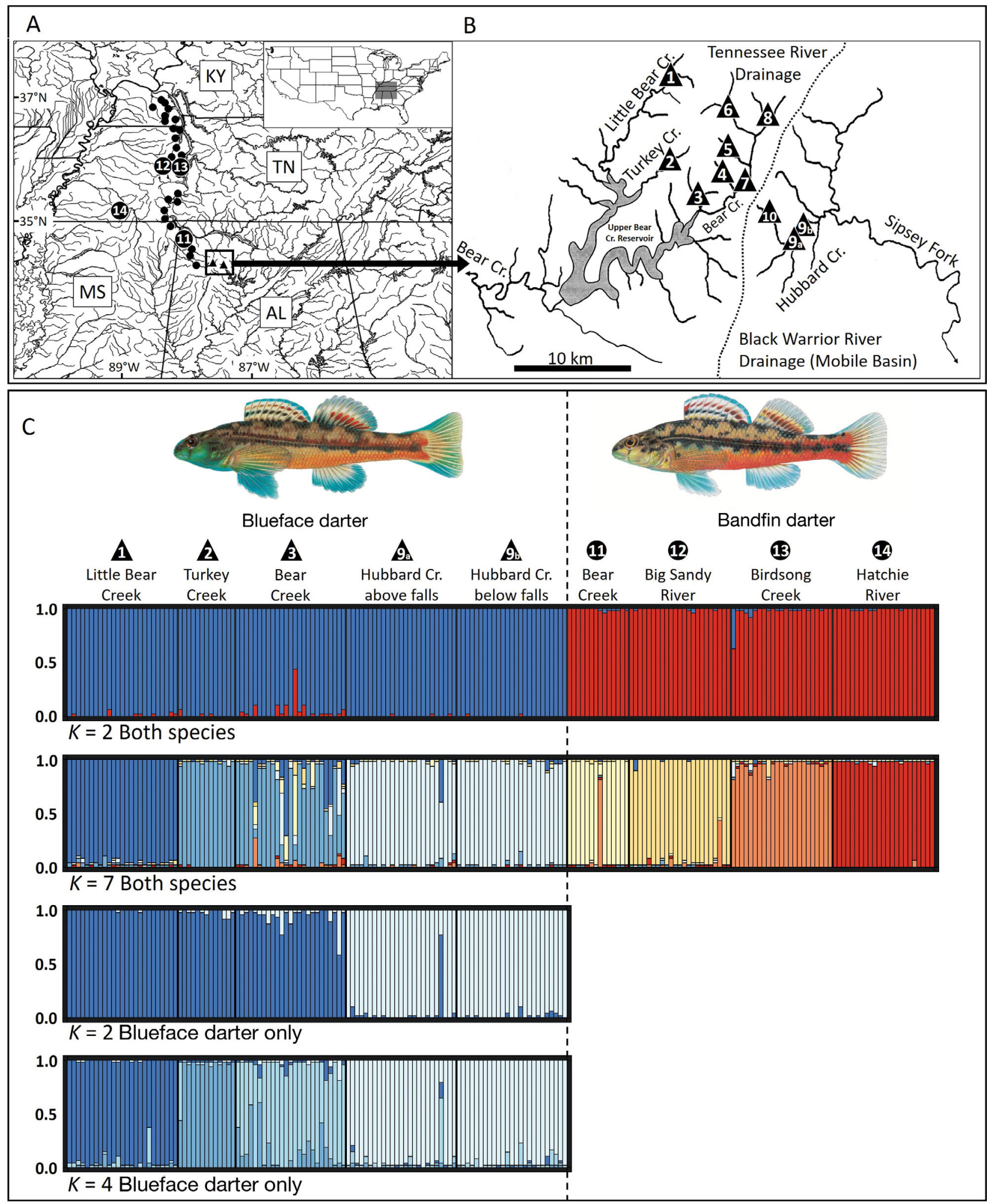

Fig. 1. (A) Geographical distribution of blueface darter Etheostoma cyanoprosopum (triangles) and bandfin darter E. zonistium (circles). Numbered symbols represent sample sites corresponding to Table 1. (B) Complete distribution of blueface darter, including boundary between the Tennessee-Black Warrior River drainage divide. (C) STRUCTURE bar plots for differing levels of hierarchical analysis. Each bar represents an individual, and colors represent proportion of assignment to STRUCTURE inferred clusters $(K)$, with shades of blue for STRUCTURE groups primarily associated with blueface darter individuals, and red/orange/yellow for bandfin darters 
tions in tributaries of the Bear Creek system has important conservation implications because recent studies have shown that this type of fragmentation may negatively impact small stream fishes more than previously thought (Skalski et al. 2008, Franssen 2012, Hudman \& Gido 2013, Fluker et al. 2014b). Finally, a waterfall of moderate elevation (Kinlock Falls, approx. $4.5 \mathrm{~m}$ ) represents a putative barrier to connectivity for the blueface darter within the Hubbard Creek system. It is unknown whether there is contemporary connectivity for the species above and below the waterfall or if there is a potential waterfall effect that may result in 1-way gene flow from upstream to downstream. In combination with the potential isolating mechanisms listed above, increased sedimentation from poor land use practices (e.g. clear-cut logging, gravel and sand mining) are suspected contributors to declines in both occurrence and abundance of the blueface darter across its range (Kuhajda 2004).

This study analyzed microsatellite DNA loci and mtDNA sequence data from the blueface darter and its sister species, the bandfin darter E. zonistium, to evaluate the following multiple objectives involving patterns of genetic variation for the blueface darter. (1) Patterns of genetic structure and diversity were compared among blueface darter populations and populations of the sister bandfin darter to evaluate distinctiveness and to estimate potential loss of diversity since diverging from a common ancestor. Because microsatellite DNA loci used in this study differed from loci developed by Kozal et al. (2017a), tests of distinctiveness between the 2 species were first conducted to ensure loci used herein could confidently discriminate the species. In addition, larger sample sizes and broader geographic coverage of blueface darters in this study allow more confident estimates of genetic diversity and potential for genetic admixture between species. (2) Patterns of genetic structure and diversity were assessed for blueface darter populations across the Tennessee-Black Warrior River drainage divide, with the null hypothesis of no significant differences. (3) Genetic structure and diversity were evaluated among populations in the Bear Creek system to test for the possibility of reservoirinduced fragmentation. (4) Levels of genetic structure and diversity were compared above and below Kinlock Falls in the Hubbard Creek system to test for a potential waterfall isolation effect. Collectively, these results will provide managing agencies with information to assist with future conservation efforts for this rare species.

\section{MATERIALS AND METHODS}

\subsection{Sample collection and DNA extraction}

Blueface darters were collected by seine from 10 localities in the Little Bear, Turkey, and Bear Creek systems of the Tennessee River drainage and the Hubbard Creek system of the Black Warrior River drainage (Table 1, Fig. 1). Bandfin darters were collected by seine from 4 localities across the species' distribution (Table 1, Fig. 1), each of which were shown to be genetically distinct by Kozal et al. (2017a). Tissue samples were taken via pelvic or caudal fin clips and preserved in $95 \%$ ethanol. Following tissue sampling, fishes were either released live at the point of capture or preserved in $10 \%$ formalin and deposited as vouchers into the Arkansas State University Museum of Zoology or the University of Alabama Ichthyological Collection. Whole genomic DNA was extracted from tissues using the DNeasy ${ }^{\circledR}$ Blood and Tissue Kit (Qiagen) according to manufacturer protocols.

\subsection{Microsatellite DNA genotyping and DNA sequencing}

In total, 113 blueface and 83 bandfin darter samples were genotyped for 8 microsatellite DNA loci with primers originally designed for the Cherokee darter Etheostoma scotti (Esc18, Esc26b, Esc68, $E s c 132 b$; Gabel et al. 2008), rainbow darter $E$. caeruleum (Eca46EPA, Eca48EPA, ECa49EPA; Tonnis 2006), and candy darter E. osburni (EosD107; Switzer et al. 2008). Amplification of loci was achieved using PCR with the GoTaq ${ }^{\circledR}$ Flexi DNA Polymerase Kit (Promega) at a total reaction volume of $13 \mu \mathrm{l}$. Each reaction contained 10 to $100 \mathrm{ng}$ template DNA, 1X colorless buffer, $2.4 \mathrm{mM} \mathrm{MgCl}_{2}, 0.24 \mathrm{mM}$ dNTP mixture, $0.4 \mu \mathrm{M}$ of each primer, and $0.5 \mathrm{U}$ Taq polymerase, and the reaction was brought to volume with autoclaved ultrapure water. Thermal cycling conditions included an initial denaturation step of $95^{\circ} \mathrm{C}$ for $60 \mathrm{~s}$ followed by 35 cycles of $95^{\circ} \mathrm{C}$ for $30 \mathrm{~s}, 56^{\circ} \mathrm{C}$ for $30 \mathrm{~s}$, and $72^{\circ} \mathrm{C}$ for $90 \mathrm{~s}$, and a final extension step of $72^{\circ} \mathrm{C}$ for $15 \mathrm{~min}$. Final reactions were conducted with forward primers labeled with either $5^{\prime}$ 6-FAM or 5' HEX fluorophores, and amplified products were electrophoresed with GeneScan ${ }^{\mathrm{TM}}$ ROX $500^{\mathrm{TM}}$ size standard on an ABI 3730 Genetic Analyzer (University of Maine DNA Sequencing Facility). Microsatellite DNA fragment size was determined using GeneScan ${ }^{\circledR}$ analysis software (Applied Biosystems) 
Table 1. Location and number of blueface darter Etheostoma cyanoprosopum and bandfin darter E. zonistium samples obtained for analysis of mitochondrial DNA (mtDNA) and for microsatellite (msat) DNA loci. Map ID represents collection sites in Fig. 1

\begin{tabular}{|c|c|c|c|c|c|c|}
\hline $\begin{array}{l}\text { Species/ } \\
\text { drainage }\end{array}$ & ID & Stream system & $\begin{array}{c}\text { Latitude } \\
\left({ }^{\circ} \mathrm{N}\right)\end{array}$ & $\begin{array}{l}\text { Longitude } \\
\left({ }^{\circ} \mathrm{W}\right)\end{array}$ & mtDNA & msat \\
\hline \multicolumn{7}{|l|}{ Blueface darter } \\
\hline \multirow[t]{8}{*}{ Tennessee River } & 1 & Little Bear Creek & 34.41825 & 87.60293 & 1 & 25 \\
\hline & 2 & Turkey Creek & 34.36372 & 87.60761 & & 13 \\
\hline & 3 & Bear Creek & 34.32992 & 87.57977 & & 25 \\
\hline & 4 & Bear Creek & 34.35167 & 87.56167 & 2 & \\
\hline & 5 & Bear Creek & 34.36222 & 87.54833 & 2 & \\
\hline & 6 & Bear Creek & 34.39286 & 87.55408 & 2 & \\
\hline & 7 & Bear Creek & 34.33972 & 87.54722 & 2 & \\
\hline & 8 & Bear Creek & 34.38361 & 87.52417 & 2 & \\
\hline \multirow[t]{3}{*}{ Black Warrior River } & $9 a$ & Hubbard Creek above Kinlock Falls & 34.30768 & 87.50340 & 4 & 25 \\
\hline & $9 \mathrm{~b}$ & Hubbard Creek below Kinlock Falls & 34.30875 & 87.50225 & 1 & 25 \\
\hline & 10 & Hubbard Creek & 34.32361 & 87.51694 & 2 & \\
\hline \multicolumn{7}{|l|}{ Bandfin darter } \\
\hline \multirow{3}{*}{ Tennessee River } & 11 & Bear Creek & 34.83091 & 88.05857 & & 14 \\
\hline & 12 & Big Sandy River & 35.80539 & 88.33439 & & 23 \\
\hline & 13 & Birdsong Creek & 35.91634 & 88.11398 & & 23 \\
\hline Hatchie River & 14 & West Fork Spring Creek & 35.08152 & 89.11192 & & 23 \\
\hline
\end{tabular}

and verified manually by 2 independent researchers using Peak Scanner ${ }^{\mathrm{TM}}$ (Applied Biosystems) and Flexibin v.2.0 (Amos et al. 2007). Microsatellite DNA data generated in this study and associated specimen data are available from the Dryad Digital Repository (accession numbers available at https://doi.org/ 10.5061/dryad.92j4913).

A subset of 18 blueface darters from each of the distinct drainage basins (Tennessee River $=11$, Black Warrior River $=7$; Table 1 ) was amplified for the mtDNA cytochrome $b$ (cyt $b$ ) gene using the forward and reverse primers and adapted PCR cycling conditions of Song et al. (1998). Adapted conditions included using the GoTaq ${ }^{\circledR}$ Flexi DNA Polymerase Kit with the following thermal profile: an initial denaturation step of $94^{\circ} \mathrm{C}$ for 5 min followed by 35 cycles of $94^{\circ} \mathrm{C}$ for $60 \mathrm{sec}, 56^{\circ} \mathrm{C}$ for $60 \mathrm{~s}$, and $72^{\circ} \mathrm{C}$ for $90 \mathrm{~s}$ and a final extension step of $72^{\circ} \mathrm{C}$ for $5 \mathrm{~min}$. Amplified products were purified using the QIAquick® PCR Purification Kit (Qiagen) and sequenced on an Applied Biosystems 3730 DNA Analyzer (Keck DNA Sequencing Lab, Yale University). Additional blueface darter cyt $b$ sequences (Tennessee River = 5, Black Warrior River $=11$ ) were obtained from Kozal et al. (2017b) and were manually aligned with DNA sequences generated in this study using BioEdit v.7.2.5 (Hall 1999). All DNA sequences generated in this study were submitted to GenBank under accession numbers MN365950 to MN365952.

\subsection{Genetic diversity and population structure}

Conformity of microsatellite DNA loci to HardyWeinberg equilibrium (HWE) and linkage disequilibrium (LD) were assessed using GENEPOP v.4.2 (Raymond \& Rousset 1995) with Bonferroni corrections (Rice 1989). Genetic diversity was estimated in Arlequin v.3.5 (Excoffier \& Lischer 2010) as mean number of alleles per locus $(A)$, observed heterozygosity $\left(H_{0}\right)$, and expected heterozygosity $\left(H_{\mathrm{e}}\right)$. The program HPRARE (Kalinowski 2005) was used to estimate number of private allelic richness and allelic richness $(A R)$ per population. To account for sample size variability, $A R$ provides an unbiased estimate of number of alleles per locus independent of sample size by scaling all populations to the smallest sample size (Kalinowski 2005). Kruskal-Wallis and Mann-Whitney $U$ tests were used to assess significance of differences in genetic diversity $\left(A, A R\right.$, and $\left.H_{\mathrm{e}}\right)$.

Population genetic structure was assessed for microsatellite DNA loci at differing hierarchical levels using Bayesian cluster analysis in the program STRUCTURE v.2.3.4 (Pritchard et al. 2000). Using adaptable models, STRUCTURE probabilistically assigns individuals to clusters $(K)$ with minimized deviations from HWE and linkage equilibrium. All structure analyses were conducted with the correlated allele frequencies model (Falush et al. 2003), assumed admixture, no a priori assignments of individuals to groups, and 10 replicates of 
200000 iterations (20000 burn-in). The first level of assessment in STRUCTURE included all 196 individuals of genotyped blueface and bandfin darters to evaluate patterns of global structuring and potential admixture between species. A second independent structure analysis was conducted only with the 113 blueface darter samples to assess potential fine-scale genetic structure among populations. This hierarchical approach is thought to provide more robust depictions of genetic structure for differing scales of analysis, especially for large or complex datasets or cases in which population substructure is obscured in global analyses (e.g. Vähä et al. 2007). Following runs, appropriate $K$ values were determined by examination of the mean estimated $\ln$ probability of data $[\ln \mathrm{P}(K)]$ and the ad hoc statistic $\Delta K$ (Evanno et al. 2005) in the program Structure Harvester (Earl \& vonHoldt 2012).

Genetic structure and divergence were further evaluated for differing hierarchical levels with analysis of molecular variance (AMOVA) of microsatellite and mtDNA data in Arlequin. First, microsatellite data were used to estimate differentiation between all blueface and bandfin darter samples. Second, both microsatellite and mtDNA data were used to estimate the extent of differentiation between blueface darter populations across the Tennessee-Black Warrior River drainage divide. Isolation by distance among blueface darter sampling locations was assessed with Mantel tests in Arlequin, using microsatellite DNA-based $F_{\mathrm{ST}}$ values plotted against the shortest distance along the stream network between locations. Significance of $F$-statistics, including pairwise population comparisons, and Mantel tests were assessed with 10000 permutations.

\subsection{Effective population size and demographic history}

Contemporary effective population size $\left(N_{\mathrm{e}}\right)$ of blueface and bandfin darter populations was estimated from microsatellite DNA data with the program $\mathrm{N}_{\mathrm{E}}$ ESTIMATOR v.2.1 (Do et al. 2014). Estimates of $N_{\mathrm{e}}$ were conducted with the bias-corrected version of the LD method (Waples \& Do 2010) with $P_{\text {crit }}=0.05$ (the minimum frequency for included alleles) and jackknife-based CIs as recommended by Gilbert \& Whitlock (2015). Long-term effective population sizes $\left(N_{\mathrm{e}}\right)$ were estimated for both species independently using microsatellite DNA data with the program migrate-n v.3.7.2 (Beerli 2018).
As suggested by Beerli (2009), a variety of initial exploratory runs were conducted under both Bayesian and maximum likelihood search strategies with varying length and number of short and long chains, in addition to differing heating schemes. Following initial exploratory runs, the following parameter set provided the most reliable $N_{\mathrm{e}}$ estimates: maximum likelihood search strategy, random subset of 15 individuals per population, Brownian motion model, starting theta $(\Theta)$ values estimated from $F_{\mathrm{ST}}$, and adaptive heating scheme with 4 chains (starting temperatures of 1.0, 1.5, 3.0, and $100000)$. Three independent runs were conducted for each species using the above parameter set with 10 short chains (50000 sampled genealogies recorded every 100 steps) and 2 long combined chains (500000 sampled genealogies recorded every 100 steps). Theta estimates (and 95\% CI) from the 3 independent runs were averaged and converted to long-term $N_{\mathrm{e}}$ using the equation $\Theta=$ $4 N_{\mathrm{e}} \mu$ with the mutation rate $(\mu)$ of $5 \times 10^{-4}$. Microsatellite DNA mutation rates have not been estimated for darters, so the above mutation rate for common carp Cyprinus carpio (Yue et al. 2007) was used, which is similar to rates from zebrafish Danio rerio (Shimoda et al. 1999) and other vertebrates (Ellegren 2000). Difference in long-term $N_{\mathrm{e}}$ between species was assessed with a Mann-Whitney $U$-test.

The program BOTTLENECK v. 1.2.02 (Piry et al. 1999) was used to test for recent declines (i.e. within the past few dozen generations) in population size for both blueface and bandfin darter populations. Tests were conducted with 5000 replications using the 2-phase model with a proportion of 0.95 singlestep mutations and 0.12 variance of multi-step mutations (Piry et al. 1999, Cristescu et al. 2010). The significance of $H_{\mathrm{e}}$ excess compared to $H_{\text {eq }}$ (the heterozygosity expected based on number of alleles and sample size) was evaluated with Wilcoxon signrank tests. The $M$-ratio method (Garza \& Williamson 2001, Williamson-Natesan 2005) was used to evaluate the possibility of prolonged, severe, or older reductions in $N_{\mathrm{e}}$ for blueface and bandfin darter populations. The programs M_P_Val.exe and Critical_M.exe (Garza \& Williamson 2001) were used to estimate the ratio of the number of alleles to the range in allele size $(M)$ and population-specific critical $M$ values $\left(M_{\mathrm{c}}\right)$. Population-specific $M$-ratios were estimated with the following parameter set, which is considered conservative by Garza \& Williamson (2001): 2-phase model with $90 \%$ singlestep mutations, mean size of non-1-step mutations = 
3.5, and pre-bottleneck $\Theta$ values of 10. M_P_Val.exe was run with 10000 simulations to test the probability that a smaller $M$-ratio would be expected under equilibrium conditions.

\section{RESULTS}

\subsection{Characteristics of microsatellite DNA loci and mtDNA sequences}

For microsatellite DNA loci, 8 of the 72 locuspopulation comparisons significantly deviated from $\mathrm{HWE}_{i} 5$ of these were significant following correction. However, deviations were not prevalent in 1 locus or population. Only 1 of the 28 comparisons among microsatellite DNA locus pairs showed significant deviation for LD (Eca48EPA and EosD107); however, this was not significant following correction. Because there were no clear patterns of deviation from HWE and LD for specific loci, all 8 loci were retained for final analyses.

When aligned with the 16 cyt $b$ sequences obtained from Kozal et al. (2017b), the complete mtDNA dataset consisted of 34 individual blueface darter cyt $b$ sequences (Bear Creek system $=16$, Hubbard Creek system $=18$ ). The cyt $b$ dataset was trimmed from 1140 to $1113 \mathrm{bp}$ due to missing data in the $5^{\prime}$ region of the gene. A total of 7 unique mtDNA haplotypes were identified among the 34 individuals. One haplotype was shared by 28 individuals ubiquitously throughout the range of the species, including the Bear Creek system $(\mathrm{n}=14)$ and the Hubbard Creek system $(\mathrm{n}=14)$. The remaining 6 haplotypes were harbored by single individuals ( 2 in the Bear Creek system and 4 in the Hubbard Creek system).

\subsection{Genetic diversity}

The number of alleles per locus ranged from 6 to 38 for the blueface darter (1-24 at the population level) and 17 to 56 for the bandfin darter (3-24 at the population level). At the population level, average measures of genetic diversity $\left(A, A R, H_{\mathrm{e}}\right)$ were generally lower for the blueface darter compared to the bandfin darter (Table 2), and these differences were significant for median values $(A$ : $z=-2.03, \mathrm{p}=0.04 ; A R: z=-2.19, \mathrm{p}=0.03 ; H_{\mathrm{e}}: z=$ $-2.11, p=0.03)$. Genetic diversity was not significantly different between blueface darter populations across the Tennessee-Black Warrior River drainage divide nor above and below Kinlock Falls in the Hubbard Creek system ( $\mathrm{p}>0.05$ for $A, A R$, $H_{\mathrm{e}}$ Table 2). However, when comparing differences in genetic diversity among blueface darter populations in the Bear Creek system (i.e. Little Bear, Turkey, and Bear creeks; Table 2), median values were significantly different $(A: H=9.70, \mathrm{p}<$ 0.01; $A R: H=7.84, \mathrm{p}<0.02 ; H_{\mathrm{e}}: H=6.41, \mathrm{p}<$ 0.05). Post hoc tests revealed that these differences were largely driven by significant population pairwise comparisons between Turkey (lower median values) and Bear creeks ( $\mathrm{p}<0.05$ for $A, A R, H_{\mathrm{e}}$; Table 2).

Table 2. Sample sizes and genetic diversity estimates (averaged over 8 microsatellite DNA loci) for blueface darter Etheostoma cyanoprosopum and bandfin darter E. zonistium included in this study. Population identifier (ID) is mapped and listed in Fig. 1 and Table 1. $N$ : number of individuals; $N A$ : total number of alleles; $A$ : mean number of alleles per locus; $A R$ : allelic richness; $P A$ : private allelic richness; $H_{\mathrm{o}}$ : heterozygosity observed; $H_{\mathrm{e}}$ : heterozygosity expected

\begin{tabular}{|c|c|c|c|c|c|c|c|c|}
\hline Species/location & ID & $N$ & $N A$ & $A$ & $A R$ & $P A$ & $H_{\mathrm{o}}$ & $H_{\mathrm{e}}$ \\
\hline \multicolumn{9}{|l|}{ Blueface darter } \\
\hline Little Bear Creek & 1 & 25 & 72 & 9.00 & 7.37 & 0.32 & 0.684 & 0.749 \\
\hline Turkey Creek & 2 & 13 & 51 & 6.38 & 6.38 & 0.27 & 0.714 & 0.780 \\
\hline Bear Creek & 3 & 25 & 100 & 12.50 & 10.08 & 0.91 & 0.750 & 0.820 \\
\hline Hubbard Creek above falls & $9 a$ & 25 & 67 & 8.38 & 7.07 & 0.30 & 0.704 & 0.706 \\
\hline Hubbard Creek below falls & $9 b$ & 25 & 67 & 8.38 & 7.31 & 0.24 & 0.665 & 0.698 \\
\hline Population mean & & & 71.4 & 8.93 & 7.64 & 0.41 & 0.703 & 0.751 \\
\hline \multicolumn{9}{|l|}{ Bandfin darter } \\
\hline Bear Creek & 11 & 14 & 53 & 6.63 & 6.62 & 1.20 & 0.761 & 0.762 \\
\hline Big Sandy River & 12 & 23 & 131 & 16.38 & 12.74 & 3.27 & 0.875 & 0.878 \\
\hline Birdsong Creek & 13 & 23 & 99 & 12.38 & 10.23 & 1.51 & 0.864 & 0.847 \\
\hline Hatchie River & 14 & 23 & 89 & 11.13 & 9.06 & 4.63 & 0.713 & 0.797 \\
\hline Population mean & & & 93.0 & 11.63 & 9.66 & 2.65 & 0.803 & 0.821 \\
\hline
\end{tabular}


Table 3. AMOVA of microsatellite DNA loci and mtDNA for differing levels of hierarchical groupings of blueface darter Etheostoma cyanoprosopum and bandfin darter E. zonistium. The source of variation column defines the hierarchical test for each estimated fixation index $(F) . F_{\mathrm{ct}}$ explains variation between the two groups (species). $F_{\text {sc }}$ explains variation among populations within each group (species). $F_{\text {is }}$ explains variation among individuals within populations. $F_{\text {it }}$ explains variation of individuals relative to the total of all individuals. *Significant results $(\mathrm{p}<0.01)$. (-) No hierarchical results, as we were only able to test for a difference between the 2 drainages with mtDNA.

\begin{tabular}{|c|c|c|}
\hline $\begin{array}{l}\text { Species/ } \\
\text { data type }\end{array}$ & Source of variation & $\begin{array}{c}\text { Fixation } \\
\text { index }\end{array}$ \\
\hline $\begin{array}{l}\text { Both } \\
\text { microsatellites }\end{array}$ & $\begin{array}{l}\text { Between species } \\
\text { Among populations within species } \\
\text { Among individuals within populations } \\
\text { Within individuals }\end{array}$ & $\begin{array}{l}F_{\mathrm{CT}}=0.083^{*} \\
F_{\mathrm{SC}}=0.113^{*} \\
F_{\mathrm{IS}}=0.020 \\
F_{\mathrm{IT}}=0.203^{*}\end{array}$ \\
\hline $\begin{array}{l}\text { Blueface darter } \\
\text { microsatellites }\end{array}$ & $\begin{array}{l}\text { Between Tennessee-Black Warrior } \\
\text { drainages } \\
\text { Among populations within drainages } \\
\text { Among individuals within populations } \\
\text { Within individuals }\end{array}$ & $\begin{array}{l}F_{\mathrm{CT}}=0.062 \\
F_{\mathrm{SC}}=0.053^{*} \\
F_{\mathrm{IS}}=0.057^{*} \\
F_{\mathrm{IT}}=0.163^{*}\end{array}$ \\
\hline mtDNA & $\begin{array}{l}\text { Between Tennessee-Black Warrior } \\
\text { drainages } \\
\text { Within drainages }\end{array}$ & $\begin{array}{l}F_{\mathrm{ST}}=0.014 \\
-\end{array}$ \\
\hline
\end{tabular}

\subsection{Population structure and divergence}

Bayesian STRUCTURE runs with all blueface and bandfin darter samples together suggested $K=7$ as the most likely number of clusters based on evaluation of both $\ln \mathrm{P}(K)$ and $\Delta K$ (Fig. 1 ; Figs. $\mathrm{S} 1 \& \mathrm{~S} 2$ in the Supplement at www.int-res.com/articles/suppl/n040 p133_supp.pdf). The $\Delta K$ method also revealed an additional peak at $K=2$, which corresponded to the global level of clustering between species (Fig. 1). Divergence between the 2 species was significant $\left(F_{\mathrm{CT}}=\right.$ 0.083, p $<0.01$; Table 3 ), and pairwise population comparisons showed moderate to strong structuring among their respective populations $\left(F_{\mathrm{ST}}\right.$ ranged from 0.139 to $0.254, \mathrm{p}<0.01$ for all; Table 3 ). In the $K=7$ configuration, all 4 bandfin darter populations were resolved as relatively discrete groups with minimal admixture. Similarly, blueface darter populations from Little Bear, Turkey, and Hubbard creeks were resolved in relatively discrete groups with minimal admixture; however, approximately $40 \%$ of individuals from the Bear Creek population showed mixed assignment with other groups, and the remaining individuals assigned strongly in the same cluster with Turkey Creek (Fig. 1). Clusters recovered in the $K=7$ scenario were supported by significant $F_{\mathrm{ST}}$ values (Tables $3 \& 4$ ) with the exception of the Bear Creek population of blueface darter, which showed weak but significant divergence compared to Turkey Creek $\left(F_{\mathrm{ST}}=0.059, \mathrm{p}<0.01\right)$ despite being largely assigned to the same cluster in STRUCTURE plots (Fig. 1).

Independent STRUCTURE runs with only blueface darter samples suggested $K=4$ as the most likely number of clusters based on evaluation of $\ln \mathrm{P}(K)$, but $K=2$ was suggested by the $\Delta K$ method (Fig. 1; Figs. S3 \& S4). In both scenarios, individuals above and below Kinlock Falls in the Hubbard Creek system were resolved in the same cluster (Fig. 1), and this was corroborated by a non-significant $F_{\mathrm{ST}}$ value (Table 4). Blueface darter populations across the Tennessee-Black Warrior River divide were resolved

Table 4. Estimated pairwise fixation indices $\left(F_{\mathrm{ST}}\right)$, based on 8 microsatellite DNA loci, among populations of blueface darter Etheostoma cyanoprosopum and bandfin darter E. zonistium (separated by dashed line). All values significant ( $p<0.00001)$ unless noted (ns: not significant). Population numbers are mapped and listed in Fig. 1 and Table 1

\begin{tabular}{|c|c|c|c|c|c|c|c|c|c|}
\hline Population & 1 & 2 & 3 & $9 a$ & $9 b$ & 11 & 12 & 13 & 14 \\
\hline 1. Little Bear Creek & - & & & & & & & & \\
\hline 2. Turkey Creek & 0.115 & - & & & & & & & \\
\hline 3. Bear Creek & 0.060 & 0.059 & - & & & & & & \\
\hline 9a. Hubbard Creek above falls & 0.161 & 0.131 & 0.092 & - & & & & & \\
\hline 9b. Hubbard Creek below falls & 0.133 & 0.132 & 0.062 & $0.004^{\mathrm{ns}}$ & - & & & & \\
\hline 11. Bear Creek & 0.139 & 0.152 & 0.108 & 0.203 & 0.173 & - & & & \\
\hline 12. Big Sandy River & 0.177 & 0.171 & 0.155 & 0.230 & 0.211 & 0.095 & - & & \\
\hline 13. Birdsong Creek & 0.150 & 0.171 & 0.141 & 0.219 & 0.204 & 0.102 & 0.113 & - & \\
\hline 14. Hatchie River & 0.205 & 0.202 & 0.177 & 0.254 & 0.228 & 0.140 & 0.180 & 0.160 & - \\
\hline
\end{tabular}


as discrete clusters in the $K=2$ scenario; however, this difference was not significant in the hierarchical AMOVA $\left(F_{\mathrm{CT}}=0.062, \mathrm{p}=0.10\right.$; Table 3$)$ despite significant low to moderate levels of divergence between all of the pairwise population comparisons between drainages $\left(F_{\mathrm{ST}}\right.$ ranged from 0.062 to 0.161 , $\mathrm{p}<0.01$ for all; Table 4). The mtDNA-based AMOVA comparing between drainages revealed no significant divergence (Table 3 ). The $K=4$ scenario was most consistent with patterns of significant divergence based on pairwise population comparisons of $F_{\text {ST }}$ (Table 2). For example, individuals from the 3 populations in the Bear Creek system generally assign with high probability to their respective cluster, and individuals from the Hubbard Creek system assign to their own cluster (Fig. 1). Independent Mantel tests indicated no pattern of isolation by distance among all blueface darter populations $\left(\mathrm{r}^{2}=\right.$ $0.46, p=0.08$ ) nor among Bear Creek populations of the blueface darter $\left(\mathrm{r}^{2}=-0.73, \mathrm{p}=0.83\right)$.

\subsection{Effective population size and demographic history}

Four of the 9 contemporary $N_{\mathrm{e}}$ estimates resulted in values of infinity (Table 5). $\mathrm{N}_{\mathrm{E}}$ ESTIMATOR was able to calculate harmonic mean values of $N_{\mathrm{e}}$ for 3 blueface darter populations (range 14-630) and 2 bandfin darter populations (range 67-113). In all but one population estimate, the upper bound of the $95 \%$ CI was infinity (Table 5). Three independent runs in Migrate-n resulted in highly consistent estimates of long-term $N_{\mathrm{e}}$ for populations of blueface darter $(95 \%$ CIs from all runs overlapped). When averaged over the 3 runs, estimates of $N_{\mathrm{e}}$ ranged from 290 to 896 (mean = 485) for blueface darter populations (Table 5, Fig. S5). Despite exploratory efforts to improve long-term $N_{\mathrm{e}}$ estimates for bandfin darter populations, variation was greater among the 3 independent Migrate-n runs when compared to blueface darter estimates. However, $95 \%$ CIs overlapped for 2 of 3 estimates in all but one population (Big Sandy River). When averaged over the 3 runs, estimates of $N_{\mathrm{e}}$ ranged from 712 to 4130 (mean = 1879) for bandfin darter populations (Table 5, Fig. S5). When compared between species, median estimates of long-term $N_{\mathrm{e}}$ were significantly lower for blueface darter $(z=-3.83, \mathrm{p}<0.01)$.

The BOTTLENECK test results indicated a modeshift distortion of allele proportions for the Turkey Creek population of blueface darter. However, evaluation of Wilcoxon-sign rank tests revealed no significant excess of $H_{\mathrm{e}}$ (i.e. no evidence for recent bottleneck) for the 9 populations examined ( $p>0.05$ for all). Alternatively, population-specific $M$-ratios were significantly lower than critical $M$ values for 4 of 5 blueface darter populations and 3 of 4 bandfin darter populations (Table 5).

\section{DISCUSSION}

\subsection{Comparisons of genetic structure and diversity between blueface and bandfin darters}

The application of genetic data to conservation planning for imperiled species has expanded vastly over the past few decades, but resolving taxonomic uncertainty and understanding population genetic structure, isolation, and levels of genetic diversity and $N_{\mathrm{e}}$ remain as primary goals in the field of conservation genetics (Frankham 1995, 2010, DeSalle \& Amato 2004, Hunter et al. 2018). Resolving taxonomic uncertainty for imperiled species intuitively involves comparisons of genetic, morphological, and other biological characteristics with closely related species. However, measures of genetic diversity and $N_{\mathrm{e}}$ are often considered for imperiled species without com-

Table 5. Microsatellite-based estimates of theta $(\Theta)$ derived from the program Migrate-n and corresponding estimates of long-term effective population size $\left(N_{\mathrm{e}}\right)$. Contemporary estimates of $N_{\mathrm{e}}$ were determined using the linkage disequilibrium (LD) method in $\mathrm{N}_{\mathrm{E}}$ ESTIMATOR. $N_{\mathrm{e}}$ estimates are followed by $95 \% \mathrm{CI}$ in parentheses. Critical $M$ values $\left(M_{\mathrm{c}}\right)$ are followed by $M$-ratios for each population. ${ }^{*}$ Significant values $(\mathrm{p}<0.05)$

\begin{tabular}{|lcccc|}
\hline Species/location & $N_{\mathrm{e}}$ Migrate-n & $N_{\mathrm{e}} \mathrm{LD}$ & $M_{\mathrm{c}}$ & $\begin{array}{c}M^{-} \\
\text {ratio }\end{array}$ \\
\hline Blueface darter & & & & \\
Little Bear Creek & $438(392-491)$ & $630(26-\infty)$ & 0.653 & $0.523^{*}$ \\
Turkey Creek & $307(274-345)$ & $14(4-526)$ & 0.604 & $0.546^{*}$ \\
Bear Creek & $886(803-1004)$ & $\infty(52-\infty)$ & 0.653 & 0.658 \\
Hubbard Creek & & & & \\
$\quad$ above falls & $290(263-320)$ & $466(40-\infty)$ & 0.647 & $0.576^{*}$ \\
below falls & $495(456-551)$ & $\infty(37-\infty)$ & 0.647 & $0.606^{*}$ \\
Bandfin darter & & & & \\
Bear Creek & $712(631-807)$ & $\infty(12-\infty)$ & 0.613 & $0.361^{*}$ \\
Big Sandy River & $4130(3676-4634)$ & $113(30-\infty)$ & 0.651 & $0.615^{*}$ \\
Birdsong Creek & $1347(1209-1506)$ & $67(19-\infty)$ & 0.651 & $0.617^{*}$ \\
Hatchie River & $1329(1194-1488)$ & $\infty(35-\infty)$ & 0.651 & 0.740 \\
\hline
\end{tabular}


parisons to close relatives. Ideally, levels of genetic diversity for imperiled species are best characterized by comparisons to sister species or close relatives using the same DNA loci (e.g. Frankham 1997, Spielman et al. 2004, Fluker et al. 2010). Thus, the first objective of this study was to assess patterns of genetic structure and diversity among blueface and bandfin darter populations to evaluate distinctiveness and to estimate potential loss of diversity since diverging from a common ancestor.

Results from STRUCTURE and AMOVA analyses in this study corroborate the genetic distinctiveness of the blueface darter as demonstrated by Kozal et al. (2017a). Further, the results of this study and that by Kozal et al. (2017a) provide strong evidence that blueface and bandfin darters do not share contemporary gene flow, nor do they exhibit patterns of hybridization or genetic introgression, a phenomenon relatively common among darters (Keck \& Near 2009, Near et al. 2011).

Estimates of genetic diversity $\left(A, A R, H_{\mathrm{e}}\right)$ were all significantly lower for blueface darter populations compared to populations of the sister bandfin darter. This finding fits with predictions of Frankham (1996) that genetic variation will be greater in species with larger geographic distributions (i.e. bandfin darter), but the reduction in diversity renders blueface darter populations more susceptible to stochastic events, changing environmental conditions, and reduced fitness (Reed \& Frankham 2003, Spielman et al. 2004). Based on 25 microsatellite DNA loci not used in this study and differing sample sizes, Kozal et al. (2017a) reported mean estimates of genetic diversity for blueface $\left(A=3.06 ; H_{\mathrm{e}}=0.36 ; \mathrm{n}=20\right)$ and bandfin $(A=$ 5.09; $H_{\mathrm{e}}=0.66 ; \mathrm{n}=98$ ) darter populations substantially lower compared to our estimates (Table 2). Differences in estimates of genetic diversity between this study and Kozal et al. (2017a) may be explained in part by differences in sample sizes, microsatellite loci used, or a combination of both, but the number of loci and sample sizes used in this study were adequate for confident estimates of population genetic structure and diversity (see Ruzzante 1998, Hale et al. 2012, Arthofer et al. 2018). Despite these differences, reanalysis of microsatellite DNA data obtained from Kozal et al. (2017b) showed significantly lower genetic diversity $(A: z=4.80, \mathrm{p}<0.01$; $\left.H_{\mathrm{e}}: z=4.56, \mathrm{p}<0.01\right)$ for blueface darter populations compared to bandfin darter populations.

Estimates of contemporary $N_{\mathrm{e}}$ among populations of both species using the LD method were somewhat uninformative based on large CIs and several point estimates of infinity, which are assumed as infinitely large estimates due to sampling error (Do et al. 2014, Gilbert \& Whitlock 2015; Table 2). However, Waples \& Do (2010) suggest that estimates of the lower bound of the CI can provide information about plausible limits of $N_{\mathrm{e}}$ that may be useful in conservation applications. While statistical comparisons of contemporary $N_{\mathrm{e}}$ between species were not possible, relative comparisons of populations with point estimates and of the lower bound of the CI suggest that contemporary $N_{\mathrm{e}}$ may be somewhat comparable between the species. The low point estimate and lower bound of the Turkey Creek population of blueface darter is suggestive of lower $N_{\mathrm{e}}$ compared to other populations. Despite this possible difference, BOTTLENECK analyses failed to detect recent declines in $N_{\mathrm{e}}$ for populations of either species.

Comparisons of long-term $N_{\mathrm{e}}$ between species and evaluation of deeper bottlenecks using $M$-ratio statistics were more robust than contemporary estimates. Overall, long-term $N_{\mathrm{e}}$ of the blueface darter was significantly lower and approximately one-third of bandfin darter estimates (Table 5). Estimates of $N_{\mathrm{e}}$ for the Big Sandy River population of bandfin darter were unusually high, possibly resulting from higher variation in Migrate-n runs (Fig. S5). However, when this population was removed from statistical tests for differences in long-term $N_{\mathrm{e}}$, the difference between species remained significantly lower for blueface darter populations. Interestingly, $M$-ratios indicated significant reductions in $N_{\mathrm{e}}$ for all but one population of each species (Table 5). These results can be interpreted as evidence for bottlenecks that were prolonged, severe, or old enough that populations may have had time to recover (Garza \& Williamson 2001, Williamson-Natesan 2005). For the blueface darter, the Bear Creek population has the largest long-term $N_{\mathrm{e}}$, with no evidence of historic or recent bottlenecks, which likely reflects relative stability and a greater amount of suitable habitat remaining within the Bear Creek system (Fig. 1). However, all other populations exhibit signatures of bottlenecks that are likely associated with isolation between drainages (i.e. Hubbard Creek) and reservoir-induced fragmentation (i.e. Little Bear and Turkey creeks). Although bandfin darter populations had higher relative $N_{\mathrm{e}}$, all 3 populations in the Tennessee River drainage showed evidence for genetic bottlenecks based on $M$-ratio analyses (Table 5). Given the propensity for finescale population isolation observed for several closely related darters in the subgenus Ulocentra (Powers \& Warren 2009, Harrington \& Near 2012), it is likely that reductions in $N_{\mathrm{e}}$ for Tennessee River populations of bandfin darter are associated with 
patterns of genetic differentiation (Fig. 1, Table 4) and, thus, isolating mechanisms within the Tennessee River drainage (Kozal et al. 2017a).

In conservation genetic studies, the quantification of genetic diversity and $N_{\mathrm{e}}$ provide comparable measures to determine the status of populations, identify processes that affect populations, and better understand susceptibility of populations to changing environmental conditions (Lande 1988, DeSalle \& Amato 2004, Frankham 2005). Direct comparisons of genetic diversity and $N_{\mathrm{e}}$ for imperiled species with sister or closely related species allow for more specific predictions about the patterns and processes that have affected imperiled species and their populations. For example, Fluker et al. (2010) found that genetic diversity of the endangered watercress darter Etheostoma nuchale was significantly lower compared to its common, widespread sister species (Gulf darter E. swaini), likely the result of a small number of founders at speciation. Although genetic diversity and $N_{\mathrm{e}}$ were reduced for watercress darter populations, rendering them more susceptible to stochastic events, demographic analyses suggested that $N_{\mathrm{e}}$ had a long-term pattern of stability reflecting the environmental stability of habitats (Fluker et al. 2010). The present study revealed a similar pattern of reduced genetic diversity and $N_{\mathrm{e}}$ for the narrowly distributed blueface darter compared to the widespread sister bandfin darter. The distributional pattern of the blueface darter, i.e. small distributional range on the margin of the widespread sister bandfin darter, in conjunction with the upland isolation of the blueface darter on the Cumberland Plateau (versus lowland Gulf Coastal Plain for the bandfin darter) is indicative of peripheral isolation or peripatric speciation (Wiley 1981, Wiley \& Mayden 1985, Coyne \& Orr 2004). Patterns of genetic structure, diversity, and $N_{\mathrm{e}}$ between the species fit with predictions of peripatric speciation and suggest that initial divergence between the 2 species involved a founder event in upland habitats of the Cumberland Plateau. $M$-ratio statistics suggest that populations of both species have experienced reductions in $N_{\mathrm{e}}$ since speciation, likely due to natural drainage level isolation, in addition to reservoir-induced fragmentation for blueface darter populations in the Bear Creek system.

\subsection{Genetic variation across the Tennessee-Black Warrior River drainage divide}

Freshwater fishes often have unique patterns of population genetic structuring because they are confined within the drainage basins they inhabit, and life-history or dispersal characteristics may limit their ability for interdrainage migration (Berendzen et al. 2008, Fluker et al. 2014a). The peculiar occurrence of the blueface darter in headwater tributaries of the Bear Creek system of the Tennessee River drainage and the Hubbard Creek system of the Black Warrior River drainage (Fig. 1) raises questions about processes leading to this distributional pattern and potential connectivity. The hypothesis that the blueface darter gained access to the Black Warrior River drainage from the Tennessee River drainage via headwater piracy (Dycus \& Howell 1974, Boschung \& Mayden 2004) is supported by distributional patterns of close relatives and other fish species. For example, all close relatives of the blueface darter (i.e. bandfin darter, firebelly darter E. pyrrhogaster, and Chickasaw darter E. cervus) are distributed in coastal plain habitats of the Tennessee, Hatchie, Obion, and Forked Deer River drainages, with no historical occurrences in the Mobile Basin (Powers \& Mayden 2003, Kozal et al. 2017a). At least 2 other fishes (pretty shiner Lythrurus bellus and rough shiner Notropis baileyi) have their distributions in the Mobile Basin and in the Bear Creek system of the Tennessee River drainage, which are also hypothesized to be the results of stream capture events where headwater tributaries of the 2 drainages interdigitate (Wall 1968, Boschung \& Mayden 2004).

The lack of significant genetic divergence between blueface darter populations across the TennesseeBlack Warrior River drainage divide based on hierarchical AMOVA of both mtDNA and microsatellites (Table 3) indicates that the species has a relatively recent history in the Black Warrior River drainage. However, STRUCTURE analyses recovered the Hubbard Creek population as a distinct cluster compared to Bear Creek populations in all scenarios except the $K=2$ between-species comparison (Fig. 1). Further, all pairwise $F_{\mathrm{ST}}$ comparisons among Hubbard Creek and Bear Creek populations revealed significant low to moderate differentiation (Table 4). Collectively, these results suggest a lack of ongoing gene flow across the Tennessee-Black Warrior River drainage divide, and enough time has passed since their isolation for accumulation of slight differences in allele frequencies.

\subsection{Genetic variation within the Bear Creek system}

Upper Bear Creek Reservoir was completed in 1978, resulting in the inundation of approximately 
half of the free-flowing stream reaches in the Bear Creek system historically occupied by the blueface darter. Based on extensive status surveys (Kuhajda \& Mayden 2002), Kuhajda (2004) considered the blueface darter extirpated from historic sites inundated by, and downstream of, the reservoir. Preferred habitat of the blueface darter is found above and below riffles over bedrock and cobble in small low-gradient streams (Kuhajda 2004), suggesting that lentic habitats of Upper Bear Creek Reservoir may represent inhospitable habitat for the species. Thus, genetic structure and diversity were evaluated among populations in the Bear Creek system to test for the possibility of reservoir-induced fragmentation (e.g. Skalski et al. 2008, Franssen 2012, Hudman \& Gido 2013, Fluker et al. 2014b). While it can be difficult to disentangle historical versus contemporary patterns of genetic structuring when assessing for reservoirinduced fragmentation of stream fishes, data from molecular markers with differing evolutionary rates can provide testable predictions (see Fluker et al. 2014 b). For example, concordant patterns of significant genetic structuring for both mtDNA and microsatellites among populations separated by the reservoir would be indicative of historical structuring likely in place prior to reservoir construction. Alternatively, significant patterns of genetic structuring based on microsatellites, but not mtDNA, would indicate contemporary genetic structuring possibly induced by reservoir fragmentation.

With the exception of 2 singleton mtDNA haplotypes, a single common and abundant haplotype was shared broadly across all Bear Creek system populations, indicating a lack of historical isolation among Little Bear, Turkey, and Bear Creek populations. This scenario is consistent with a single panmictic population historically, and contemporary isolation among creek systems is recent enough that mtDNA haplotype frequencies remain unchanged by the lineage sorting process (Funk \& Omland 2003, Omland et al. 2006). However, microsatellite-based STRUCTURE and AMOVA analyses revealed significant low to moderate structuring among populations. For example, the $K=7$ STRUCTURE scenario (both species included) largely resolved individuals from Turkey Creek and Bear Creek populations in the same cluster but provided support for the distinctiveness of the Little Bear Creek population (Fig. 1). The $K=4$ scenario (blueface darter only) indicated a pattern of substructuring among all Bear Creek populations consistent with significant pairwise $F_{\mathrm{ST}}$ comparisons (Fig. 1, Table 4). Genetic structuring among Bear Creek populations was not explained by distance among sampling localities, suggesting that inhospitable habitat of the reservoir likely represents a barrier to gene flow among the remaining populations in Little Bear, Turkey, and Bear creeks. Interestingly, all measures of genetic diversity were significantly lower in the Turkey Creek population when compared to Bear Creek, which may be related to the limited remaining preferred habitat in Turkey Creek (Fig. 1). Collectively, results from mtDNA suggest that blueface darter populations in the Bear Creek system were historically connected, but contemporary patterns of genetic structuring revealed by microsatellites are consistent with reservoir-induced fragmentation.

\subsection{Genetic variation above and below Kinlock Falls in the Hubbard Creek system}

Given the small amount of stream length occupied by the blueface darter in the Hubbard Creek system (approx. 5.4 km; Kuhajda 2004), even small withinstream barriers such as Kinlock Falls may reduce intrapopulation connectivity and result in patterns of 1-way gene flow from upstream to downstream (Meeuwig et al. 2010). Lack of significant $F_{\mathrm{ST}}$ values between individuals above and below Kinlock Falls, in conjunction with high assignment probability of all individuals to a single genetic cluster in STRUCTURE analyses, suggests either that genetic exchange is not impeded by the waterfall or that isolation is recent enough that allele frequency differences are not detectable. Status surveys in the Hubbard Creek system indicated that the majority of blueface darter occurrences are above Kinlock Falls (Kuhajda \& Mayden 2002). Given this distributional pattern, it is possible that blueface darters downstream of Kinlock Falls represent a sink population receiving 1-way gene flow from the source population above the falls. Conservation plans for the Hubbard Creek population should include more detailed studies to monitor potential connectivity of blueface darters above and below Kinlock Falls to evaluate the possibility of a source (upstream) and sink (downstream) scenario.

\subsection{Conclusions}

Among the >1000 North American freshwater fishes, approximately $10 \%$ of species diversity is estimated to remain undescribed (Jelks et al. 2008, April et al. 2011). Further, data deficiencies for many described and undescribed imperiled North American 
freshwater fishes delay determinations of conservation status by entities such as the IUCN, US Fish and Wildlife Service, and state agencies (e.g. Jelks et al. 2008). Results from this study provide 3 main conclusions that will help prioritize conservation planning for the rare blueface darter. First, results from this study corroborate the distinctiveness of the blueface darter as demonstrated by Kozal et al. (2017a). Lower levels of genetic diversity and long-term $N_{\mathrm{e}}$ for the blueface darter, compared to the sister bandfin darter, are indicative of differences in geographic range size and are possible signatures of a founder event at speciation. Although no recent genetic bottlenecks were detected for the blueface darter, signatures of historic reductions in $N_{\mathrm{e}}$, small geographic range size, and reduced genetic diversity render the species more susceptible to local extirpation compared to the more widespread bandfin darter. Second, analysis of mtDNA data suggested that the Hubbard Creek population was the result of a recent interdrainage transfer from the Bear Creek system. While hierarchical AMOVA did not recover significant genetic differentiation between blueface darter populations across the Tennessee-Black Warrior River drainage divide, Bayesian STRUCTURE analyses and pairwise population comparisons of $F_{\mathrm{ST}}$ suggest contemporary isolation between the drainages. Thus, it is recommended that Bear Creek populations of blueface darter (i.e. Little Bear, Turkey, and Bear creeks) be treated independently from the Hubbard Creek population in management and conservation planning. Third, results from this study revealed possible reservoir-induced fragmentation for the Bear Creek populations of blueface darter, a scenario in which historical connectivity among tributaries of the Bear Creek system is now severed by the inhospitable habitat of Upper Bear Creek Reservoir. Coupled with the infrequent occurrence of blueface darter captures in Turkey Creek (Kuhajda \& Mayden 2002, P. O'Neil pers. comm.), low genetic diversity of this population is of particular concern. Continued monitoring and quantitative surveys would help to better characterize occurrence, abundance, and changes in census size for blueface darter populations in the isolated tributaries of the Bear Creek system.

Acknowledgements. We thank M. G. Bennett, A. T. Hook, J. H. Howell, T. K. Lee, S. M. Mitchell, D. A. Neely, and M. Sandel for assistance with field sampling and J. Khudamrongsawat for assistance with DNA sequencing. Fish illustrations were used with permission from J. R. Tomelleri. This work was funded by an Arkansas State University Faculty Research Award (FRAC), with additional support provided by the Arkansas State University Department of Biological Sciences, the University of Alabama Department of Biological Sciences, and the Tennessee Aquarium Conservation Institute. Collection permits were issued by the Alabama Department of Conservation and Natural Resources and the Tennessee Wildlife Resources Agency. Sampling for this project was approved by the Arkansas State University Institutional Animal Care and Use Committee (IACUC Protocol number 747441-1).

\section{LITERATURE CITED}

Amos W, Hoffman JI, Frodsham A, Zhang L, Best S, Hill AV (2007) Automated binning of microsatellite alleles: problems and solutions. Mol Ecol Notes 7:10-14

April J, Mayden RL, Hanner RH, Bernatchez L (2011) Genetic calibration of species diversity among North America's freshwater fishes. Proc Natl Acad Sci USA 108: 10602-10607

Arthofer W, Heussler C, Krapf P, Schlick-Steiner BC, Steiner FM (2018) Identifying the minimum number of microsatellite loci needed to assess population genetic structure: a case study in fly culturing. Fly (Austin) 12:13-22

Beerli P (2009) How to use MIGRATE or why are Markov chain Monte Carlo programs difficult to use? In: Bertorelle G, Bruford MW, Hauffe HC, Annapaola R, Vernesi $C$ (eds) Population genetics for animal conservation. Cambridge University Press, Cambridge, p 42-79

Beerli P (2018) Migrate-n v.3.7.2: estimation of population sizes and gene flow using the coalescent. https:// peterbeerli.com/migrate-html5/index.html (accessed 27 May 2019)

Berendzen PB, Simons AM, Wood RM, Dowling TE, Secor CL (2008) Recovering cryptic diversity and ancient drainage patterns in eastern North America: historical biogeography of the Notropis rubellus species group (Teleostei: Cypriniformes). Mol Phylogenet Evol 46: 721-737

Boschung HT, Mayden RL (2004) Fishes of Alabama. Smithsonian Books, Washington, DC

Coyne JA, Orr HA (2004) Speciation. Sinauer, Sunderland, MA

Cristescu R, Sherwin WB, Handasyde K, Cahill V, Cooper DW (2010) Detecting bottlenecks using BOTTLENECK 1.2.02 in wild populations: the importance of the microsatellite structure. Conserv Genet 11:1043-1049

DeSalle R, Amato G (2004) The expansion of conservation genetics. Nat Rev Genet 5:702-712

Do C, Waples RS, Peel D, Macbeth GM, Tillett BJ, Ovenden JR (2014) NeEstimator v2: re-implementation of software for the estimation of contemporary effective population size $\left(N_{\mathrm{e}}\right)$ from genetic data. Mol Ecol Resour 14:209-214

Dycus DL, Howell WM (1974) Fishes of the Bankhead National Forest of Alabama. Alabama Department of Conservation and Natural Resources, Montgomery, AL

*Earl DA, vonHoldt BM (2012) STRUCTURE HARVESTER: a website and program for visualizing STRUCTURE output and implementing the Evanno method. Conserv Genet Resour 4:359-361

*Ellegren H (2000) Microsatellite mutations in the germline: implications for evolutionary inference. Trends Genet 16: 551-558

Evanno G, Regnaut S, Goudet J (2005) Detecting the number of clusters of individuals using the software STRUCTURE: a simulation study. Mol Ecol 14:2611-2620 
Excoffier L, Lischer HEL (2010) Arlequin suite ver 3.5: a new series of programs to perform population genetics analyses under Linux and Windows. Mol Ecol Resour 10: 564-567

Falush D, Stephens M, Pritchard JK (2003) Inference of population structure using multilocus genotype data: linked loci and correlated allele frequencies. Genetics 164:1567-1587

*Fluker BL, Kuhajda BR, Lang NJ, Harris PM (2010) Low genetic diversity and small long-term population sizes in the spring endemic watercress darter, Etheostoma nuchale. Conserv Genet 11:2267-2279

Fluker BL, Kuhajda BR, Harris PM (2014a) The influence of life-history strategy on genetic differentiation and lineage divergence in darters (Percidae: Etheostomatinae). Evolution 68:3199-3216

Fluker BL, Kuhajda BR, Harris PM (2014b) The effects of riverine impoundment on genetic structure and gene flow in two stream fishes in the Mobile River basin. Freshw Biol 59:526-543

Frankham R (1995) Conservation genetics. Annu Rev Genet 29:305-327

Frankham R (1996) Relationship of genetic variation to population size in wildlife. Conserv Biol 10:1500-1508

Frankham R (1997) Do island populations have less genetic variation than mainland populations? Heredity 78: 311-327

Frankham R (2005) Genetics and extinction. Biol Conserv 126:131-140

Frankham R (2010) Where are we in conservation genetics and where do we need to go? Conserv Genet 11:661-663

Franssen NR (2012) Genetic structure of a native cyprinid in a reservoir-altered stream network. Freshw Biol 57: 155-165

Funk DJ, Omland KE (2003) Species-level paraphyly and polyphyly: frequency, causes, and consequences, with insights from animal mitochondrial DNA. Annu Rev Ecol Evol Syst 34:397-423

Gabel JM, Dakin EE, Freeman BJ, Porter BA (2008) Isolation and identification of eight microsatellite loci in the Cherokee darter (Etheostoma scotti) and their variability in other members of the genera Etheostoma, Ammocrypta, and Percina. Mol Ecol Resour 8:149-151

Garza JC, Williamson EG (2001) Detection of reduction in population size using data from microsatellite loci. Mol Ecol 10:305-318

Gilbert KJ, Whitlock MC (2015) Evaluating methods for estimating local effective population size with and without migration. Evolution 69:2154-2166

*Hale ML, Burg TM, Steeves TE (2012) Sampling for microsatellite-based population genetic studies: 25 to 30 individuals per population is enough to accurately estimate allele frequencies. PLOS ONE 7:e45170

Hall TA (1999) BioEdit: a user-friendly biological sequence alignment editor and analysis program for Windows 95/98/NT. Nucleic Acids Symp Ser 41:95-98

Harrington RC, Near TJ (2012) Phylogenetic and coalescent strategies of species delimitation in snubnose darters (Percidae: Etheostoma). Syst Biol 61:63-79

* Hollingsworth PR Jr, Near TJ (2009) Temporal patterns of diversification and microendemism in Eastern Highland endemic barcheek darters (Percidae: Etheostomatinae). Evolution 63:228-243

Hudman SP, Gido KB (2013) Multi-scale effects of impoundments on genetic structure of creek chub (Semotilus atromaculatus) in the Kansas River basin. Freshw Biol 58: 441-453

*HHunter ME, Hoban SM, Bruford MW, Segelbacher G, Bernatchez L (2018) Next-generation conservation genetics and biodiversity monitoring. Evol Appl 11: 1029-1034

* IUCN (2018) The IUCN Red List of Threatened Species. Version 2018-2. www.iucnredlist.org (accessed 12 Dec 2018)

Jelks HL, Walsh SJ, Burkhead NM, Contreras-Balderas S and others (2008) Conservation status of imperiled North American freshwater and diadromous fishes. Fisheries (Bethesda, MD) 33:372-407

Kalinowski ST (2005) hp-rare 1.0: a computer program for performing rarefaction on measures of allelic richness. Mol Ecol Notes 5:187-189

Keck BP, Near TJ (2009) Patterns of natural hybridization in darters (Percidae: Etheostomatinae). Copeia 2009: 758-773

Kozal LC, Simmons JW, Mollish JM, MacGuigan DJ and others (2017a) Phylogenetic and morphological diversity of the Etheostoma zonistium species complex with the description of a new species endemic to the Cumberland Plateau of Alabama. Bull Peabody Mus Nat Hist 58: 263-286

Kozal LC, Simmons JW, Mollish JM, MacGuigan DJ and others (2017b) Data from: Phylogenetic and morphological diversity of the Etheostoma zonistium species complex with the description of a new species endemic to the Cumberland Plateau of Alabama. Dryad Digital Repository. https://doi.org/10.5061/dryad.s7h6b

Kuhajda BR (2004) Blueface darter Etheostoma sp. cf. zonistium. In: Mirarchi RE, Garner JT, Mettee MF, O'Neil PE (eds) Alabama wildlife, Vol 2. Imperiled aquatic mollusks and fishes. University of Alabama Press, Tuscaloosa, AL, p 233-234

Kuhajda BR, Mayden RL (1995) Discovery of a new species of snubnose darter (Percidae, Etheostoma) endemic to the Cumberland Plateau in Alabama. Assoc Southeast Biol Bull 42:111-112

Kuhajda BR, Mayden RL (2002) Status survey of the blueface darter, Etheostoma sp. cf. zonistium, in upper Sipsey Fork (Mobile Basin) and Bear Creek (Tennessee River drainage) of Alabama. Final report to US Fish and Wildlife Service, Jackson, MS

* Lande R (1988) Genetics and demography in biological conservation. Science 241:1455-1460

* Lundberg JG, Kottelat M, Smith GR, Stiassny ML, Gill AC (2000) So many fishes, so little time: an overview of recent ichthyological discovery in continental waters. Ann Mo Bot Gard 87:26-62

*Mayden RL, Knott KE, Clabaugh JP, Kuhajda BR, Lang NJ (2005) Systematics and population genetics of the coldwater (Etheostoma ditrema) and watercress (Etheostoma nuchale) darters, with comments on the Gulf darter (Etheostoma swaini) (Percidae: subgenus Oligocephalus). Biochem Syst Ecol 33:455-478

Mayden RL, Wood RM, Lang NJ, Dillman CB, Switzer JF (2006) Phylogenetic relationships of species of the darter genus Etheostoma (Perciformes: Percidae): evidence from parsimony and Bayesian analyses of mitochondrial cytochrome $b$ sequences. In: Lozano-Vilano MDL, Contreras-Balderas AJ (eds) Studies of North American desert fishes in honor of EP (Phil) Pister, conservationist. Universidad Autonoma de Nuevo Leon, Monterrey, p 20-39 Meeuwig MH, Guy CS, Kalinowski ST, Fredenberg WA 
(2010) Landscape influences on genetic differentiation among bull trout populations in a stream-lake network. Mol Ecol 19:3620-3633

NatureServe (2018) NatureServe Explorer: an online encyclopedia of life [web application]. Version 7.1. NatureServe, Arlington, VA. http://explorer.natureserve.org (accessed 25 Jan 2019)

Near TJ, Bossu CM, Bradburd GS, Carlson RL and others (2011) Phylogeny and temporal diversification of darters (Percidae: Etheostomatinae). Syst Biol 60:565-595

Omland KE, Baker JM, Peters JL (2006) Genetic signatures of intermediate divergence: population history of Old and New World Holarctic ravens (Corvus corax). Mol Ecol 15:795-808

Page LM (1983) Handbook of darters. TFH Publications, Neptune City, NJ

Page LM, Smith PW, Burr BM, Mayden RL (1985) Evolution of reproductive behaviors in percid fishes. Bull Ill Nat Hist Surv 33:275-295

Piry S, Luikart G, Cornuet JM (1999) BOTTLENECK: a computer program for detecting recent reductions in the effective population size using allele frequency data. J Hered 90:502-503

Powers SL, Mayden RL (2003) Etheostoma cervus: a new species from the Forked Deer River system in western Tennessee with comparison to Etheostoma pyrrhogaster (Percidae: subgenus Ulocentra). Copeia 2003:576-582

Powers SL, Warren ML Jr (2009) Phylogeography of three snubnose darters (Percidae: subgenus Ulocentra) endemic to the southeastern U.S. Coastal Plain. Copeia 2009: $523-528$

* Pritchard JK, Stephens M, Donnelly P (2000) Inference of population structure using multilocus genotype data. Genetics 155:945-959

Raymond M, Rousset F (1995) GENEPOP (version 1.2): population genetics software for exact tests and ecumenicism. J Hered 86:248-249

Reed DH, Frankham R (2003) Correlation between fitness and genetic diversity. Conserv Biol 17:230-237

Rice WR (1989) Analyzing tables of statistical tests. Evolution 43:223-225

Ruzzante DE (1998) A comparison of several measures of genetic distance and population structure with microsatellite data: bias and sampling variance. Can J Fish Aquat Sci 55:1-14

Shimoda N, Knapik EW, Ziniti J, Sim C and others (1999) Zebrafish genetic map with 2000 microsatellite markers. Genomics 58:219-232

Skalski GT, Landis JB, Grose MJ, Hudman SP (2008) Genetic structure of creek chub, a headwater minnow, in an impounded river system. Trans Am Fish Soc 137: 962-975

Editorial responsibility: Mike Bruford,

Cardiff, UK
Song CB, Near TJ, Page LM (1998) Phylogenetic relations among percid fishes as inferred from mitochondrial cytochrome $b$ DNA sequence data. Mol Phylogenet Evol 10:343-353

Spielman D, Brook BW, Frankham R (2004) Most species are not driven to extinction before genetic factors impact them. Proc Natl Acad Sci USA 101:15261-15264

Starnes WC, Etnier DA (1986) Drainage evolution and fish biogeography of the Tennessee and Cumberland rivers drainage realm. In: Hocutt $\mathrm{CH}$, Wiley EO (eds) The zoogeography of North American freshwater fishes. John Wiley \& Sons, New York, NY, p 325-361

* Switzer JF, Welsh SA, King TL (2008) Microsatellite DNA primers for the candy darter, Etheostoma osburni and variegate darter, Etheostoma variatum, and crossspecies amplification in other darters (Percidae). Mol Ecol Resour 8:335-338

Tonnis BD (2006) Microsatellite DNA markers for the rainbow darter, Etheostoma caeruleum (Percidae), and their potential utility for other darter species. Mol Ecol Notes 6:230-232

* Turner TF, Trexler JC, Kuhn DN, Robison HW (1996) Lifehistory variation and comparative phylogeography of darters (Pisces: Percidae) from the North American central highlands. Evolution 50:2023-2036

*Vähä JP, Erkinaro J, Niemelä E, Primmer CR (2007) Lifehistory and habitat features influence the withinriver genetic structure of Atlantic salmon. Mol Ecol 16: 2638-2654

Wall BR Jr (1968) Studies on the fishes of the Bear Creek drainage of the Tennessee River system. MS thesis, University of Alabama, Tuscaloosa, AL

WWaples RS, Do C (2010) Linkage disequilibrium estimates of contemporary $N_{\mathrm{e}}$ using highly variable genetic markers: a largely untapped resource for applied conservation and evolution. Evol Appl 3:244-262

*Warren ML Jr, Burr BM, Walsh SJ, Bart HL Jr and others (2000) Diversity, distribution, and conservation status of the native freshwater fishes of the southern United States. Fisheries (Bethesda, Md) 25:7-31

Wiley EO (1981) Phylogenetics: the theory and practice of phylogenetic systematics. John Wiley \& Sons, New York, NY

Wiley EO, Mayden RL (1985) Species and speciation in phylogenetic systematics, with examples from the North American fish fauna. Ann Mo Bot Gard 72:596-635

Williamson-Natesan EG (2005) Comparison of methods for detecting bottlenecks from microsatellite loci. Conserv Genet 6:551-562

\% Yue GH, David L, Orban L (2007) Mutation rate and pattern of microsatellites in common carp (Cyprinus carpio L.). Genetica 129:329-331

Submitted: February 7, 2019; Accepted: August 30, 2019 Proofs received from author(s): October 27, 2019 